\title{
OBSERVATIONS CONCERNING THE PRODUCTION AND EXCRETION OF CHO- LESTEROL IN MAMMALS. XVI. THE RELATIONSHIP OF THE LIVER TO THE CONTENT AND CONTROL OF PLASMA CHOLESTEROL ESTER ${ }^{1}$
}

\author{
BY MEYER FRIEDMAN AND SANFORD O. BYERS
}

(From the Harold Brunn Institute, Mount Zion Hospital, San Francisco 15, Calif.)

(Submitted for publication February 4, 1955 ; accepted May 12, 1955)

Earlier studies of this series $(1,2)$, and also those of Gould and his associates (3), have demonstrated that the liver serves as the chief source of plasma total cholesterol in the intact animal. This same organ also functions to remove an excess of cholesterol when present in plasma (4-7). Thus, whether the cholesterol content of plasma is experimentally reduced or increased, the liver functions to restore the physiological status quo. Only severe interference, therefore, with the hepatic function or perhaps drastic alteration of the physico-chemical integrity of plasma cholesterol itself $(8,9)$ can prevent such restoration.

Despite this certainty that the liver serves as the indispensable source of plasma cholesterol, it has never been ascertained whether this organ discharges only free cholesterol of which a large portion will be esterified elsewhere or whether it supplies both free and conjugated forms to the plasma. It has been tacitly assumed, however, ever since Epstein's observation (10) of the dearth of esterified cholesterol in the blood of patients suffering from severe liver disease, that the liver is probably the chief site of esterification of plasma cholesterol.

In view of this seeming absence of experimental data directly bearing upon the origin and fate of plasma cholesterol ester, the present series of experiments designed to investigate this question was undertaken. The results of these experimental observations appear to indicate that when the plasma content of esterified cholesterol is acutely reduced in the experimental animal, the liver serves as the chief, if not the indispensable source of its replacement.

\footnotetext{
1 Aided by Grants from the Life Insurance Medical Research Fund, American Heart Association, and Grant H-119 from the National Heart Institute, National Institutes of Health, Public Health Service.
}

\section{THE ROLE OF THE GASTRO-INTESTINAL TRACT (INCLUDING THE PANCREAS) IN RESTORATION OF PLASMA CHOLESTEROL ESTER}

The presence of a potent cholesterol esterase in pancreatic and intestinal fluid and the known intestinal absorption of dietary cholesterol predominantly in the ester form $(11,12)$ present the possibility that the chief source of plasma cholesterol ester stems from the gastro-intestinal tract. Conceivably such ester could be received by the blood via the intestinal lymph (13) or perhaps directly from the blood traversing either the pancreas or the intestinal mucosa. The following experiment was done to determine this possibility.

\section{A. Methods}

(a) Total extirpation of the gastro-intestinal tract (including the pancreas and spleen) following experimental reduction of plasma total and cholesterol ester. A series of seven anesthetized rats were subjected to plasmapheresis (2) following which the stomach, the small and large intestines, the pancreas and spleen were removed. Blood samples obtained before, immediately and 24 hours after plasmapheresis were analyzed for their total and esterified cholesterol by previously described (14) methods.

(b) Control animals. A series of 10 rats were subjected to plasmapheresis for control purposes. Blood samples obtained immediately before and immediately, 12 and 24 hours, after plasmapheresis were analyzed for their total and esterified cholesterol content.

\section{B. Results}

Despite the total absence of their entire gastrointestinal tract, including the pancreas, the experimental rats were able to restore their plasma cholesterol ester content after it had been reduced by plasmapheresis.

Thus, despite the fact that their average cholesterol ester content had been reduced from 38.0 to $9.0 \mathrm{mg}$. per $100 \mathrm{cc}$. by the plasmapheresis (see 
Table I A), 12 hours later, it had again risen to $33.0 \mathrm{mg}$. per $100 \mathrm{cc}$., a rise approximately equal to that found in the intact control rats (see and compare Table I A and I D).

These results left no doubt that replacement of acutely lost plasma cholesterol ester was a process which could proceed independently of the absorption of dietary derived cholesterol and also of the possible esterifying mechanisms present in the pancreas and intestinal mucosa.

\section{THE ROLE OF THE KIDNEY IN THE RESTORATION} OF PLASMA CHOLESTEROL ESTER

Since removal of the rat's kidney was found to alter the plasma cholesterol content (15), it seemed desirable to determine the possible role of this organ in the restoration of the plasma cholesterol ester level previously reduced by plasmapheresis.

\section{A. Methods}

Six male rats were plasmapheresed as above and then both kidneys were removed. Blood samples obtained before, immediately, and 24 hours after the plasmapheresis were analyzed for total and esterified cholesterol content.

\section{B. Results}

Despite the absence of kidneys, these rats appeared able to restore their lost plasma cholesterol ester as readily as the intact control animals. The average plasma ester content which was reduced from 38 to $16 \mathrm{mg}$. per $100 \mathrm{cc}$. (see Table I B) returned to $34 \mathrm{mg}$. per $100 \mathrm{cc}$., 24 hours later.

\section{THE ROLE OF THE LIVER IN THE RESTORATION} OF PLASMA CHOLESTEROL ESTER

In an earlier study of this series (2) we had observed that in the absence of sufficient hepatic tissue, the rat was not able to restore either its plasma free or esterified cholesterol if both had been previously reduced by plasmapheresis. While this study indicated that the liver was indispensable for ester replacement, it did not demonstrate necessarily that the esterification actually occurred in the liver. In other words, it can be

TABLE I

The effect of various procedures upon replacement of plasma cholesterol after experimental removal

\begin{tabular}{|c|c|c|c|c|c|c|c|c|c|c|}
\hline \multirow{3}{*}{$\begin{array}{l}\text { No. of } \\
\text { rats }\end{array}$} & \multirow{3}{*}{$\underset{(g m .)}{\text { Av. wt. }}$} & \multirow{3}{*}{$\begin{array}{c}\text { Amt. } \\
\text { blood } \\
\text { plas- } \\
\text { mapheresed } \\
c c .\end{array}$} & \multicolumn{8}{|c|}{ Plasma cholesterol (mg./100 cc.) } \\
\hline & & & \multicolumn{2}{|c|}{$\begin{array}{c}\text { Before } \\
\text { plasmapheresis }\end{array}$} & \multicolumn{2}{|c|}{$\begin{array}{l}\text { Immed. after } \\
\text { plasmapheresis }\end{array}$} & \multicolumn{2}{|c|}{$\begin{array}{l}12 \text { hrs. after } \\
\text { plasmapheresis }\end{array}$} & \multicolumn{2}{|c|}{$\begin{array}{l}24 \text { hrs. after } \\
\text { plasmapheresis }\end{array}$} \\
\hline & & & Total & Ester & Total & Ester & Total & Ester & Total & Ester \\
\hline \multicolumn{11}{|c|}{ A. Eviscerated Rats } \\
\hline 7 & $\begin{array}{c}285 \\
(230-334)^{*}\end{array}$ & $\begin{array}{c}27 \\
(23-30)\end{array}$ & $\begin{array}{c}46 \\
(38-60) \\
\pm 2.6 \dagger\end{array}$ & $\begin{array}{c}38 \\
(33-43) \\
\pm 1.6\end{array}$ & $\begin{array}{l}11 \\
(2-18) \\
\pm 1.9\end{array}$ & $\begin{array}{l}9.0 \\
(2-16) \\
\pm 1.7\end{array}$ & $\begin{array}{c}68 \\
(52-80) \\
\pm 3.0\end{array}$ & $\begin{array}{c}33 \\
(28-40) \\
\pm 1.5\end{array}$ & & \\
\hline \multicolumn{11}{|c|}{ B. Nephrectomized Rats } \\
\hline 6 & $\begin{array}{c}240 \\
(210-265)\end{array}$ & $\begin{array}{c}27 \\
(26-28)\end{array}$ & $\begin{array}{c}48 \\
(40-55) \\
\pm 2.0\end{array}$ & $\begin{array}{c}38 \\
(37-42) \\
\pm 1.3\end{array}$ & $\begin{array}{c}18 \\
(12-24) \\
\pm 1.7\end{array}$ & $\begin{array}{c}16 \\
(11-22) \\
\pm 1.6\end{array}$ & & & $\begin{array}{c}50 \\
(47-53) \\
\pm 3.2\end{array}$ & $\begin{array}{c}34 \\
(31-39) \\
\pm 2.8\end{array}$ \\
\hline \multicolumn{11}{|c|}{ C. Partially Hepatectomized Rats Given Free Cholesterol after Plasmapheresis } \\
\hline 8 & $\begin{array}{c}264 \\
(226-316)\end{array}$ & $\begin{array}{c}25 \\
(20-28)\end{array}$ & $\begin{array}{c}49 \\
(40-68) \\
\pm 2.9\end{array}$ & $\begin{array}{c}41 \\
(28-58) \\
\pm 2.8\end{array}$ & $\begin{array}{c}46 \\
(37-72) \\
\pm 4.1\end{array}$ & $\begin{array}{c}25 \\
(16-34) \\
\pm 2.2\end{array}$ & $\begin{array}{c}43 \\
(30-57) \\
\pm 2.9\end{array}$ & $\begin{array}{l}20 \\
(7-34) \\
\pm 3.3\end{array}$ & $\begin{array}{c}43 \\
(26-59) \\
\pm 3.6\end{array}$ & $\begin{array}{l}23 \\
(7-42) \\
\pm 4.2\end{array}$ \\
\hline \multicolumn{11}{|c|}{ D. Normal Rats-Control } \\
\hline 10 & $\begin{array}{c}243 \\
(209-300)\end{array}$ & $\begin{array}{c}26 \\
(22-32)\end{array}$ & $\begin{array}{c}54 \\
(44-61) \\
\pm 1.7\end{array}$ & $\begin{array}{c}40 \\
(33-48) \\
\pm 1.4\end{array}$ & $\begin{array}{c}20 \\
(10-31) \\
\pm 2.0\end{array}$ & $\begin{array}{l}16 \\
(8-31) \\
\pm 1.9\end{array}$ & $\begin{array}{c}61 \\
(46-81) \\
\pm 6.3\end{array}$ & $\begin{array}{c}36 \\
(30-42) \\
\pm 2.2\end{array}$ & $\begin{array}{c}54 \\
(44-60) \\
\pm 2.4\end{array}$ & $\begin{array}{c}40 \\
(27-45) \\
\pm 3.0\end{array}$ \\
\hline
\end{tabular}

* Range of values.

$\dagger$ Standard error of the mean. 
postulated that the liver may discharge only free cholesterol which then is subsequently esterified elsewhere.

In order to distinguish the possible role of the liver in both of these processes, it would be necessary to administer to an animal with insufficient hepatic tissue, a sufficient amount of cholesterol in the free state and then determine whether esterification of such cholesterol occurred despite inadequate liver function. This type of experiment was done in the following manner.

\section{A. Methods}

(a) Subtotal hepatectomy following experimental reduction of only plasma cholesterol ester. Eight rats were anesthetized and approximately 60 to 70 per cent of their liver was removed by a previously described technique (1). Removal of this amount of liver tissue is sufficient to prevent any restoration of lost total and esterified plasma cholesterol irrespective of the severity of the loss of cholesterol (2). Immediately following the hepatectomy, the animals were subjected to the plasmapheresis process as done above except that the resultant loss in total cholesterol was overcome by the intravenous injection of a specially prepared hypercholesteremic serum containing predominantly free cholesterol (approximately $140 \mathrm{mg}$. of free cholesterol per $100 \mathrm{cc}$.). This procedure left the rat with a markedly reduced ester but a proportionately increased increment of free cholesterol.

The hypercholesteremic serum was obtained by bleeding and collecting the serum of rats which had been injected 15 minutes previously with $2.5 \mathrm{cc}$. of a 2 per cent emulsion of cholesterol prepared as described in a previous study (16). In this latter study, it was found that after injection of this emulsion into a rat, approximately 60 to 70 per cent of the injected cholesterol disappeared immediately from the circulating blood but that increment of excess cholesterol remaining in the blood 15 minutes after injection exhibited a slow rate of disappearance comparable to that observed when cholesterol in soluble lipoprotein form is administered (4). This cholesterol also appeared to be esterified by the injected rat (16). It therefore seems probable that this remaining cholesterol is in soluble, not particulate form. It was found necessary to administer this type of hypercholesteremic serum rather than that produced by cholate (15) or Triton (9) administration because such sera invariably contain a plethora of esterified as well as free cholesterol.

Blood samples obtained before, immediately, 12 and 24 hours later were analyzed for total and ester cholesterol content.

No control animals with intact livers were administered the hypercholesteremic serum because, as already demonstrated (see Table I D), they were able to re- place their lost ester without the necessity of administering free cholesterol as a possible precursor.

\section{B. Results}

Despite the fact that the eight partially hepatectomized rats after plasmapheresis were supplied with additional free cholesterol amply sufficient for its possible esterification by extra-hepatic sources, they still were found unable to replace the esterified cholesterol lost by plasmapheresis. As Table I C demonstrates, although the total cholesterol had not been reduced after plasmapheresis because of the subsequent injection of excess free cholesterol, the average plasma ester concentration reduced by plasmapheresis to 24.0 mg. per $100 \mathrm{cc}$. actually declined further to 20 and $23 \mathrm{mg}$. per $100 \mathrm{cc}$. at 12 and 24 hours, respectively, after plasmapheresis. Failure of the free cholesterol increment to fall during this same period also indicates that it was undoubtedly in a soluble, not particulate, state or else it quickly would have been withdrawn from circulation by the R-E system (6).

IV. THE ROLE OF THE GASTRO-INTESTINAL TRACT

AND THE LIVER IN THE REMOVAL OF EXCESS

\section{CHOLESTEROL ESTER}

\section{A. Methods}

(a) Total extirpation of the gastro-intestinal tract (including pancreas and spleen) followed by injection of cholesterol ester. Five male rats (av. wt.: 319 grams) were eviscerated as described above and then each was given approximately $12 \mathrm{mg}$. of cholesterol ester in a 1.2 per cent emulsion. This emulsion was prepared by dissolving cholesterol acetate in 1 volume of warm "Sorlate" ${ }^{2}$ and diluting with 3 volumes of 0.85 per cent $\mathrm{NaCl}$ solution to yield an emulsion containing 1.2 per cent cholesterol. Blood samples obtained immediately, three and six hours after injection were analyzed for total and ester cholesterol.

A series of 10 normal rats were injected for control purposes with $12 \mathrm{mg}$. of the cholesterol ester and blood samples obtained before, immediately, 3, 6, 12 and 24 hours after injection were analyzed for total and ester cholesterol.

(b) Total hepatectomy followed by injection of cholesterol ester. A second series of five rats were similarly eviscerated but also functionally hepatectomized by ligating their hepatic artery. They also were injected with the same amount of ester cholesterol. Blood samples obtained immediately and three hours after injection were analyzed for total and ester cholesterol.

\footnotetext{
${ }^{2}$ Sorbitan monoleate polyoxyethylene (Abbott).
} 


\section{B. Results}

The normal intact rat appeared able to rid its plasma as easily of the pure cholesterol ester as of a quantitatively comparable mixture of free and ester cholesterol (4). Thus in three hours, the average ester content had fallen from 244 to 159 mg. per $100 \mathrm{cc}$. (see Table II A), and at the end of six hours, to $65 \mathrm{mg}$. per $100 \mathrm{cc}$. A similar fall in three hours was observed in the eviscerated rats (see Table II B) and the moderate lag observed at the end of six hours might have been due to the rather poor condition of these rats at this time.

The considerable fall observed in the above two series, however, was not observed in the hepatectomized rats (see Table II C). The amount of ester found at the end of three hours $(260 \mathrm{mg}$. per $100 \mathrm{cc}$.) was about the same as that present immediately after its injection. Thus, the liverless animal appears unable to rid its plasma of excess esterified cholesterol.

\section{DISCUSSION}

The data presented above demonstrate that restoration of plasma cholesterol ester lost by plasmapheresis can be effected by the eviscerated or nephrectomized animal as rapidly as by the intact animal. This suggests a total independence of the control of plasma cholesterol ester level from intestinally derived cholesterol ester. On the other hand, the failure of similar restoration of reduced plasma cholesterol ester in the partially hepatectomized animal, even when the latter is given an excess amount of free cholesterol as a possible precursor source for esterified cholesterol, strongly suggests that the liver serves as the chief, if not the indispensable source of plasma cholesterol ester. It would seem possible that the blood cholesterol esterase system described by Sperry, Brand, and Stoyanoff (17-20) might be active in restoring a reduced plasma cholesterol ester concentration to normal levels. No such restorative ability was observed in our experiments, either because the rat lacks such a system (21) or because its action is not quantitatively significant under our experimental conditions. The experimentally derived data offer an explanation for the frequently observed precipitous fall in plasma cholesterol ester component of patients suffering from severe parenchymatous hepatic disease (10).

These observations attesting as they do to the indispensability of the liver in the origin of plasma

TABLE II

The rate of disappearance of injected cholesterol ester

\begin{tabular}{|c|c|c|c|c|c|c|c|c|c|}
\hline \multirow{3}{*}{$\begin{array}{l}\text { No. of } \\
\text { rats }\end{array}$} & \multirow[b]{3}{*}{ Av. wt. } & \multicolumn{8}{|c|}{ Plasma cholesterol (mg./100 cc.) } \\
\hline & & \multicolumn{2}{|c|}{ Before injection } & \multicolumn{2}{|c|}{ Immed. after injection } & \multicolumn{2}{|c|}{ Three hrs. after injection } & \multicolumn{2}{|c|}{ Six hrs. after injection } \\
\hline & & Total & Ester & Total & Ester & Total & Ester & Total & Ester \\
\hline \multicolumn{10}{|c|}{ A. Normal Rats-Control } \\
\hline 10 & 210 & $\begin{array}{c}50 \\
(36-63) \\
\pm 2.4 \dagger\end{array}$ & $\begin{array}{c}41 \\
(28-55) \\
\pm 2.34\end{array}$ & $\begin{array}{c}266 \\
(142-319) \\
\pm 14.5\end{array}$ & $\begin{array}{c}244 \\
(123-294) \\
\pm 14.4\end{array}$ & $\begin{array}{c}168 \\
(115-204) \\
\pm 12.0\end{array}$ & $\begin{array}{c}159 \\
(138-186) \\
\pm 9.4\end{array}$ & $\begin{array}{c}114 \\
(89-149) \\
\pm 4.9\end{array}$ & $\begin{array}{c}64 \\
(45-76) \\
\pm 3.4\end{array}$ \\
\hline \multicolumn{10}{|c|}{ B. Eviscerated Rats } \\
\hline 5 & 319 & & & $\begin{array}{c}233 \\
(192-272) \\
\pm 16.0\end{array}$ & $\begin{array}{c}217 \\
(180-316) \\
\pm 17\end{array}$ & $\begin{array}{c}196 \\
(158-250) \\
\pm 19.5\end{array}$ & $\begin{array}{c}155 \\
(120-200) \\
\pm 14.8\end{array}$ & $\begin{array}{c}132 \\
(122-142) \\
\pm 7.1\end{array}$ & $\begin{array}{c}91 \\
(88-94) \\
\pm 4.5\end{array}$ \\
\hline \multicolumn{10}{|c|}{ C. Eviscerated-Hepatectomized Rats } \\
\hline 5 & 206 & & & $\begin{array}{c}283 \\
(258-302) \\
\pm 4.0\end{array}$ & $\begin{array}{c}268 \\
(243-291) \\
\pm 9.3\end{array}$ & $\begin{array}{c}298 \\
(266-397) \\
\pm 10.4\end{array}$ & $\begin{array}{c}260 \\
(234-281) \\
\pm 8.6\end{array}$ & & \\
\hline
\end{tabular}

* Range of values.

$\uparrow$ Standard error of the mean. 
cholesterol ester do not on the other hand necessarily indicate that at any given time, some small portion of this ester may not be derived from extra-hepatic sources including the intestine or blood itself. As was shown in an earlier report (5), the blood of the intact rat is constantly receiving via the thoracic duct, some esterified cholesterol from the intestine. However, not only is such receipt a slow and gradual one but it is probable that much cholesterol ester is travelling enveloped in chylomicra (22) and because of this is quickly removed by the hepatic R-E cells for subsequent transfer to the hepatic parenchymal cells (6). This probable removal of chylomicronous ester cholesterol by the hepatic R-E cell explains why the oral administration of $\mathrm{C}^{\mathbf{1 4}}$ cholesterol is not followed by the appearance of significant amounts of radioactive ester in plasma (23), despite the probable absorption of most of the radioactive cholesterol in the esterified state (11, 12).

\section{SUM MARY}

1. The rate of replacement of an experimentally reduced plasma ester cholesterol content in the rat was found to be unaffected by total removal of the entire gastro-intestinal tract (including the pancreas) and the kidneys.

2. Cholesterol ester replacement, however, was not found to occur in the drastically hepatectomized rat even when an excess of free cholesterol was administered to the animal.

3. Disappearance of injected excess esterified cholesterol occurred only in the presence of functioning liver tissue.

4. On the basis of these observations, it is concluded that the liver serves as the chief organ both for the supply and subsequent withdrawal of plasma ester cholesterol, and in so doing controls the latter's concentration in plasma at any given instant.

\section{ACKNOWLEDGMENT}

The authors wish to express their thanks and appreciation to Patricia Ryan, B. A., Gonsalo Monarque, B. S., and Clarence Omoto, B. S., for their technical assistance.

\section{REFERENCES}

1. Byers, S. O., Friedman, M., and Michaelis, F., Observations concerning the production and excretion of cholesterol in mammals. III. The source of excess plasma cholesterol after ligation of the bile duct. J. Biol. Chem., 1951, 188, 637.

2. Friedman, M., Byers, S. O., and Michaelis, F., Production and excretion of cholesterol in mammals. IV. Role of liver in restoration of plasma cholesterol after experimentally induced hypocholesteremia. Am. J. Physiol., 1951, 164, 789.

3. Gould, R. G., Campbell, D. J., Taylor, C. B., Kelly, F. B., Jr., Warren, I., and Davis, C. B., Jr., Origin of plasma cholesterol using carbon ${ }^{14}$. Federation Proc., 1951, 10, 191.

4. Friedman, M., Byers, S. O., and Gunning, B., Observations concerning production and excretion of cholesterol in mammals. VIII. Fate of injected cholesterol in the animal body. Am. J. Physiol. 1953, 172, 309.

5. Friedman, M., Byers, S. O., and Shibata, E., Observations concerning the production and excretion of cholesterol in mammals. X. Factors affecting the absorption and fate of ingested cholesterol. J. Exper. Med., 1953, 98, 107.

6. Friedman, M., Byers, S. O., and Rosenman, R. H., Observations concerning the production and excretion of cholesterol in mammals. XII. Demonstration of the essential role of the hepatic reticuloendothelial cell (Kupffer cell) in the normal disposition of exogenously derived cholesterol. Am. J. Physiol., 1954, 177, 77.

7. Friedman, M., and Byers, S. O., Observations concerning the production and excretion of cholesterol in mammals. XIV. The relationship of the hepatic reticulo-endothelial cell (Kupffer cell) to endogenously produced cholesterol. Circulation, 1954, 10, 491.

8. Byers, S. O., Friedman, M., and Rosenman, R. H. Review: On the regulation of blood cholesterol Metabolism, 1952, 1, 479.

9. Friedman, M., and Byers, S. O., The mechanism responsible for the hypercholesteremia induced by Triton WR-1339. J. Exper. Med., 1953, 97, 117.

10. Epstein, E. Z., The cholesterol partition of the blood plasma in parenchymatous diseases of the liver. Arch. Int. Med., 1931, 47, 82.

11. Mueller, J. H., The mechanism of cholesterol absorption. J. Biol. Chem., 1916, 27, 463.

12. Bollman, J. L., and Flock, E. V., Cholesterol in intestinal and hepatic lymph of the rat. Federation Proc., 1948, 7, 269.

13. Biggs, M. W., Friedman, M., and Byers, S. O., Intestinal lymphatic transport of absorbed cholesterol Proc. Soc. Exper. Biol. \& Med., 1951, 78, 641.

14. Byers, S. O., Friedman, M., and Michaelis, F., Observations concerning the production and excretion of cholesterol in mammals. I. Plasma cholesterol after bile duct ligation and free cholesterol injection. J. Biol. Chem., 1950, 184, 71.

15. Friedman, M., and Byers, S. O., Production and excretion of cholesterol in mammals. VI. Bile acid 
accumulation in production of hypercholesteremia occurring after biliary obstruction. Am. J. Physiol., 1952, 168, 292.

16. Byers, S. O., and Friedman, M., Hypercholesteremia in the rat after intravenous administration of cholesterol. J. Biol. Chem., 1949, 177, 841.

17. Sperry, W. M., and Brand, F. C., A study of cholesterol esterase in liver and brain. J. Biol. Chem., 1941, 137, 377.

18. Sperry, W. M., Cholesterol esterase in blood. J. Biol. Chem., 1935, 111, 467.

19. Sperry, W. M., and Stoyanoff, V. A., The influence of sodium glycocholate on the enzymatic synthesis and hydrolysis of cholesterol esters in blood serum. J. Biol. Chem., 1937, 117, 525.
20. Sperry, W. M., and Stoyanoff, V. A., The enzymatic synthesis and hydrolysis of cholesterol esters in blood serum. J. Biol. Chem., 1938, 126, 77.

21. Swell, L., and Treadwell, C. R., Cholesterol esterases. III. Occurrence and characteristics of cholesterol esterase of serum. J. Biol. Chem., 1950, 185, 349.

22. Byers, S. O., and Friedman, M., Observations concerning the production and excretion of cholesterol in mammals. XIII. Role of chylomicra in transport of cholesterol and lipid. Am. J. Physiol., 1954, $179,79$.

23. Hellman, L., Rosenfeld, R. S., Eidinoff, M. L., Fukushima, D. K., Gallagher, T. F., Wang, C. I., and Adlersberg, D., Isotopic studies of plasma cholesterol of endogenous and exogenous origins. $\mathrm{J}$. Clin. Invest., 1955, 34, 48. 